\title{
Analisis Variabel yang Mempengaruhi Minat Investasi Berbasis Aplikasi
}

Submitted Date :

10 August 2021

Accepted Date :

27 October 2021
Lina Affifatusholihah

Fakultas Ekonomi dan Bisnis, Universitas Sultan Ageng Tirtayasa

lina.affifatusholihah@unitirta.ac.id

Solehatin Ika Putri*

Fakultas Ekonomi dan Bisnis, Universitas Sultan Ageng Tirtayasa

putri.solehatin@untirta.ac.id

\section{Suggested Citation:}

Nurhikmah, Romadhoni, B., \& Nurinaya. (2018). Pengaruh Brand Awareness Dan Brand Attitude Terhadap Minat Pembelian Konsumen Pada Produk Indihome Di Wilayah Telekomunikasi (Witel) Makassar. Balance: Jurnal Ekonomi, 14(2), 9.

\section{Abstract:}

This study considers how the direct and indirect impact from variable of advertising attitude, brand awareness, brands attitude to interest in using online investment applications. Quantitative method for data analysis using SEM Warp PLS 7.0 application with a sample of 103 people. The results of the study stated that advertising attitude had no effect on brands attitude, brand awareness had a significant positive effect on brands attitude. Brands attitude have an effect on interest in using online investment applications. Advertising attitudes have an effect on interest in using online investment applications. Brand awareness have an effect on interest in using online investment applications. Brands attitude cannot mediate the effect of advertising attitude on interest in using online investment applications. Brands attitude mediate the effect of brand awareness on interest in using online investment applications. Conclusion in this study stated that variable of advertising attitude, brand awareness, brands attitude had direct effect to interest in using online investment applications. In addition, brands attitude had indirect effect through brand awareness to interest in using online investment applications.

Keywords: Advertising Attitude; Brands Attitude; Brand Awareness; Interest

\section{Abstrak:}

Tujuan dari penelitian ini antara lain untuk mengukur pengaruh langsung dan pengaruh tidak langsung dari variabel sikap terhadap iklan, kesadaran merek dan sikap terhadap merk pada minat menggunakan aplikasi investasi daring. Metode kuantitatif digunakan melalui analisis data menggunakan aplikasi SEM Warp PLS 7.0 dengan jumlah sampel 103 orang. Hasil penelitian menyatakan bahwa sikap terhadap iklan tidak mempengaruhi sikap terhadap merk, kesadaran merek memiliki pengaruh pada sikap terhadap merk. Minat menggunakan aplikasi investasi daring dipengaruhi oleh sikap terhadap merek. Sikap terhadap iklan mempengaruhi minat menggunakan aplikasi investasi daring. Kesadaran merek mempengaruhi minat menggunakan aplikasi investasi daring. Sikap terhadap merek pengaruh secara tidak langung pengaruh sikap terhadap iklan terhadap minat menggunakan aplikasi investasi daring. Sikap terhadap merek memediasi pengaruh kesadaran merek terhadap minat menggunakan aplikasi investasi daring. Maka kesimpulan pada penelitian ini bahwa minat menggunakan aplikasi investasi daring dipengaruhi secara langsung oleh variabel sikap terhadap merek, sikap terhadap iklan dan kesadaran merek. Adapun secara tidak langsung, minat menggunakan aplikasi investasi daring dipengaruhi oleh kesadaran merek melalui sikap terhadap merek.

Kata Kunci: Kesadaran Merek; Minat; Sikap Terhadap Iklan; Sikap Terhadap Merk

JEL Classification: M31

*Corresponding Author 


\section{Latar Belakang}

Kondisi pademi akibat virus Covid - 19 telah merubah banyak hal dalam kehidupan masyarakat dunia dan Indonesia khususnya. Perubahan tersebut terlihat pada beberapa aspek seperti perilaku masyarakat, kondisi ekonomi, sosial budaya dan lainnya. Sudah lebih dari satu tahun sebagian besar masyarakat Indonesia melakukan kegiatan dari rumah masing - masing. Salahsatu hal penting yang berubah adalah bergesernya cara aktivitas masyarakat dari kegiatan langsung (offline) menjadi serba online atau daring, seperti proses belajar mengajar, rapat, berjualan, termasuk berinvestasi.

Investasi menurut Cahya \& Setyarini (2020) yaitu memanfaatkan harta yang dimiliki pada masa sekarang untuk digunakan pada masa depan yang lebih menguntungkan dengan tujuan lebih sejahteranya hidup. Sedangkan menurut Manuel (2019) investasi berarti menyimpan asset untuk meningkatkan nilainya dengan tujuan kondisi aman ketika terjadi inflasi, agar asset semakin bertambah dan terlindungi serta sebagai jaga jaga akan kondisi darurat pada masa yang akan datang. Berbicara mengenai investasi, data menyebutkan bahwa perkembangan investasi online berbasis aplikasi terlebih ketika pandemi jumlahnya semakin meningkat. Tentu hal ini menarik untuk diteliti dan dipelajari lebih lanjut terutama hal yang menyebabkan mengapa investasi menjadi sangat digemari. Menurut data yang tercatat bahwa di Indonesia perkembangan kegiatan investasi semakin meningkat. Hal tersebut diindikasikan karena berbagai kemudahan yang dirasakan investor, terlebih dengan modal yang terbatas pun masyarakat dapat berinvestasi. Hal ini sejalan dengan hasil penelitian yang dilakukan oleh Manuel (2019) yang menyatakan ketertarikan seseorang untuk berinvestasi terutama investasi berbasis aplikasi dikarenakan cara melakukannya bisa dilakukan dengan mudah, tidak menyulitkan dan informasi terkait investasi dapat dengan mudah dijangkau. Informasi lain yang bersumber dari Badan Koordinasi Penanaman Modal dikutip melalui kontan.co.id (2021) menyatakan bahwa peningkatan investasi pada tahun 2017 dan 2018 mencapai masing - masing sebesar 678,8 T dan 721,3 T. Begitupun di tahun 2019 dan tahun 2020, menunjukkan peningkatan jumlah masyarakat yang berinvestasi. Uniknya pada masa pandemi akibat virus Corona, kegiatan investasi sekitar $95 \%$ dilakukan secara online. Selain itu jumlah masyarakat yang baru berinvestasi jumlahnya bertambah lebih dari setengahnya dan jumlah transaksi mencapai $70 \%$. Bahkan sejak awal pandemi hingga pertengahan tahun 2020 terdapat duapuluh enam ribu nasabah atau dengan total seratus empat puluh lima ribu nasabah dan meningkat 5.000 nasabah pada akhir tahun 2020.

Kegiatan investasi berbasis aplikasi yang terdaftar terus dipantau dan diatur oleh Otoritas Jasa Keuangan (OJK). Hal ini dilakukan agar masyarakat merasa aman dan terjamin dalam melakukan kegiatan investasi. Ada 59 aplikasi yang terdaftar dan diawasi oleh OJK yang dikutip dari laman ojk.go.id (2021) yaitu, Ajaib, Aplikasi android Mentimun Pay, Aplikasi Pembayaran Finnet, Aplikasi PNM Digi PT Mitra Tekno Madani, Aplikasi Seluler InvestASIK, Aplikasi Seluler Raiz Invest, Aplikasi Seluler WELMA, Aplikasi Android dan Iphone Investasi, Aplikasi Telepon Seluler Bibitnomic, Bareksa.com, Blanja Invest, Bukalapak Tanamduit, BukaReksa, cekaja.com, CROS, DOKU, finansialku, Fitur GO-POINTS Aplikasi GOJEK, fitur Reksa Dana - akseleran.co.id, fitur Reksa Dana ikredo.id, Fund ZaisanBNIS, Fundtastic (PT Chandharwealth Mandiri Indonesia), Halofina, HPAM, Internet \& Mobile Banking, Bank OCBC NISP, Bank HSBC Indonesia, Standard Chartered Bank, Investree, Invisee, IPOTFUND, IPOTGO, ITRAM, Klik Mami, Koperasi KOPOJEKA (akses internal Institusi), Max, MNC Duit, Moduit, Moinves, MOST, NOIS, OVO - Aplikasi Telepon Seluler, Panin AM, PayOr, permatanet, PG Online, Profunds, PT BNP IP - PT Indosat Tbk, PT. Talenta Digital Indonesia, Reksa Dana SAM, rol.sinarmas-am.co.id, Sinar Bahana, SPOR, SRI Online, Tanam Duit, Tokopedia, Trima Trimegah, Widget Reksa Dana - Baznas, Xdana (Xsaver, Xdana Pro, dan Xdana Syariah).

Telah banyak penelitian dalam berbagai objek yang membahas mengenai minat konsumen dalam membeli atau menggunakan produk tertentu dengan beragam variabel yang mempengaruhi dan memediasinya. Diantanya menurut Hakim \& Susilowati (2013) yang penelitiannya menghasilkan kesimpulan yakni sikap pada merek dipengaruhi secara postif dan signifikan oleh sikap terhadap iklan. Menurut Amiludin \& Kartini (2019) sikap terhadap iklan merupakan perasaan konsumen untuk dapat menyukai atau tidak suka ketika melihat sebuah iklan ditampilkan. Sedangkan menurut Ramdhani \& Abdurrahman (2021) sikap terhadap iklan merupakan tindakan lanjutan yang dilakukan konsumen setelah melihat suatu objek. Hal yang berpengaruh pada hal tersebut adalah iklan yang informatif, pengaruh yang baik dari suatu hiburan, serta pengaruh tidak baik. Penelitian yang melibatkan variabel sikap terhadap iklan antara lain menurut Hakim \& Susilowati (2013) yang penelitiannya menghasilkan kesimpulan yakni sikap pada merek dipengaruhi secara postif dan signifikan oleh sikap terhadap iklan. Adapun Ramdhani \& Abdurrahman (2021) menyatakan sikap terhadap iklan berpengaruh pada kesadaran merek. Kaitannya dengan minat, menurut Aziz \& Sulistiono (2020) sikap terhadap iklan para konsumen mempengaruhi minat berkunjung ke tempat wisata. Selanjutnya menurut Andrew (2014) dan Amalia 
(2018), sikap mengenai iklan berpengaruh terhadap minat secara positif dan signifikan. Adapun menurut Darwati \& Yulianto (2019), Priyanti et al. (2017) dan Rahmah (2015) sikap pada iklan mempengaruhi minat beli konsumen.

Sementara Hanfan (2017) menyatakan bahwasannya kesadaran merek mempengaruhi sikap terhadap merek. Kesadaran merek menurut Shah et al. (2012) dalam Dewi \& Jatra (2018) merupakan sikap konsumen yang memikirkan dan terbersit akan merek tertentu ketika disebutkan sebuah produk dengan rasa suka, loyal dan selalu menjadi pilihan prioritas dalam memakai sebuah merek. Selanjutnya menurut Dewi \& Jatra (2018), Nurhikmah et al. (2018), Sholihah (2018) kesadaran merek mempengaruhi minat beli. Adapun menurut Nurhikmah et al. (2018) terdapat pengaruh positif antara kesadaran terhadap merek pada minat membeli. Sholihah (2018) juga menyimpulkan bahwa terdapat pengaruh kesadaran merek kepada minat beli. Kesadaran merek berpengaruh pada minat beli produk kecantikan. Menurut Dewi \& Jatra (2018), Nurhikmah et al. (2018), Sholihah (2018) kesadaran merek mempengaruhi minat beli. Sementara menurut (Santoso et al., 2019) kesadaran merek berpengaruh pada minat beli produk kecantikan. Sependapat dengan Hanfan (2017), Sholihah (2018) menyimpulkan terdapat pengaruh antara kesadaran merek kepada sikap terhadap merek. Selain variabel tersebut, penelitian Azis \& Harsono (2020) menyatakan minat menabung dipengaruhi oleh banyak aspek salahsatunya oleh sikap terhadap merek. Kemudian Hanfan (2017) berpendapat bahwa minat beli dipengaruhi sikap terhadap merek. Terdapat pendapat mengenai variabel sikap terhadap merek menurut Heriyati et al. (2018) bahwa sikap terhadap merek berpengaruh pada minat pasien dalam memilih layanan kesehatan di rumah sakit. Selain itu Mardalena et al. (2018) kesadaran merek berpengaruh pada minat beli konsumen produk fashion. Muslimawati \& Wardani (2017) menyatakan terdapat pengaruh antara kesadaran terhadap minat beli air minum kemasan. Sementara menurut Sholihah (2018) terdapat pengaruh sikap terhadap merek kepada minat beli. Variabel lain yang mempengaruhi minat yaitu menurut Darwati \& Yulianto (2019) yakni sikap pada iklan mempengaruhi minat beli konsumen. Sejalan dengan Priyanti et al., (2017) bahwa sikap pada iklan memiliki pengaruh pada minat beli konsumen. Selanjutnya menurut Rahmah (2015) sikap terhadap iklan berpengaruh secara positif terhadap minat beli. Adapun Santoso et al. (2019) menambahkan variabel kesadaran merek juga berpengaruh pada minat beli produk kecantikan.

Hakim \& Susilowati (2013) menyatakan bahwa sikap terhadap iklan berpengaruh terhadap terhadap minat melalui sikap terhadap merek. Sikap terhadap merek menurut Amiludin \& Kartini (2019) merupakan kepercayaan konsumen pada sebuah merek atas dasar apa yang pernah dirasakan pada masa lalu terkait fungsi dan kualitasnya dalam memenuhi keinginan konsumen. Indikator sikap terhadap merek antara lain selalu mengingat merek tersebut, menyukai merek tersebut, dan memilih merek tersebut untuk digunakan.

Pembahasan mengenai sikap terhadap merek antara lain menurut Adisti (2017), Apsyari \& Raharjo (2018), Hakim \& Susilowati (2013) bahwa sikap terhadap merek dipengaruhi oleh kesadaran merek. Adapun menurut Hanfan (2017) kesadaran merek mempengaruhi sikap terhadap merek. Selanjutnya menurut (Sholihah, 2018) terdapat pengaruh antara kesadaran merek kepada sikap terhadap merek. Jika diteliti bersamaan dengan variabel minat, menurut Azis \& Harsono (2020) minat menabung dipengaruhi oleh banyak aspek salahsatunya oleh sikap terhadap merek. Sementara menurut Hanfan (2017) minat beli dipengaruhi sikap terhadap merek. Penelitian Heriyati et al. (2018) menghasilkan kesimpulan bahwa sikap terhadap merek berpengaruh pada minat pasien dalam memilih layanan kesehatan di rumah sakit. Mardalena et al., (2018) menyatakan bahwa kesadaran merek berpengaruh pada minat beli konsumen produk fashion. Selain itu menurut Muslimawati \& Wardani (2017) terdapat pengaruh antara kesadaran terhadap minat beli air minum kemasan. Terakhir, terdapat pengaruh sikap terhadap merek kepada minat beli menurut Sholihah (2018).

Minat menurut Putra (2014) merupakan faktor penentu yang mendorong konsumen untuk menggunakan produk tertentu. Maka sebelum proses tersebut pencarian informasi terkait produk tersebut konsumen lakukan. Penelitian yang mengkombinasikan variabel minat telah banyak dilakukan diantaranya yaitu menurut Aziz \& Sulistiono (2020) bahwasannya sikap terhadap iklan para konsumen mempengaruhi minat berkunjung ke tempat wisata. Selanjutnya menurut Andrew (2014) dan Amalia (2018), sikap mengenai iklan berpengaruh terhadap minat secara positif dan signifikan. Adapun menurut Darwati \& Yulianto (2019), Priyanti et al. (2017) dan Rahmah (2015) sikap pada iklan mempengaruhi minat beli konsumen. Sedangkan kaitannya dengan variabel kesadaran merek. Menurut Nurhikmah et al. (2018) terdapat pengaruh positif antara kesadaran terhadap merek pada minat membeli. Sholihah (2018) juga menyimpulkan bahwa terdapat pengaruh kesadaran merek kepada minat beli. 
Kesadaran merek berpengaruh pada minat beli produk kecantikan. Adapun jika diteliti bersamaan dengan variabel sikap terhadap merek menurut Azis \& Harsono (2020) minat menabung dipengaruhi oleh banyak aspek salahsatunya oleh sikap terhadap merek. Sementara menurut Hanfan (2017) minat beli dipengaruhi sikap terhadap merek. Penelitian Heriyati et al. (2018) menghasilkan kesimpulan bahwa sikap terhadap merek berpengaruh pada minat pasien dalam memilih layanan kesehatan di rumah sakit. Menurut Mardalena et al. (2018) kesadaran merek berpengaruh pada minat beli konsumen produk fashion. Selanjutnya menurut Muslimawati \& Wardani (2017) terdapat pengaruh antara kesadaran terhadap minat beli air minum kemasan. Terakhir, terdapat pengaruh sikap terhadap merek kepada minat beli menurut Sholihah (2018).

Pengembangan dari penelitian - penelitian diatas yang membahas variabel - variabel yang mempengaruhi minat secara terpisah, maka penelitian ini akan mencoba untuk mengungkapkan pengaruh langsung dan pengaruh tidak langsung dari gabungan variabel yang telah dikemukakan sebelumnya yaitu antara sikap terhadap iklan, kesadaran merek dan sikap terhadap merk pada minat menggunakan aplikasi investasi daring.

\section{Metode Penelitian}

Penelitian ini menggunakan metode kuantitatif dengan analisis data yang dilakukan dengan menggunakan Structural Equation Modelling Partial Least Square. Data diperoleh dari hasil kuesioner yang disebar secara online. Analisis data dilakukan dengan mula - mula menguji instrumen atau model pengukuran. Tahapan selanjutnya yaitu pengujian hipotesis penelitian atau uji model struktural. Instrumen pada penelitian ini dijelaskan pada tabel 1. Hasil pengembangan instrumen penelitian tersebut disebarkan kepada responden yang memenuhi kriteria. Populasi pada penelitian ini adalah seluruh responden yang berminat melakukan investasi berbasis aplikasi (online). Sedangkan teknik pengambilan sampel yaitu dengan menetapkan seluruh populasi menjadi sampel. Ukuran sampel minimum yang digunakan merujuk pendapat Sholihin \& Ratmono (2020) yaitu sepuluh kali jalur terbesar yang mengarah pada suatu konstruk tertentu. Adapun jumlah jalur terbesar terdiri atas lima jalur artinya sample minimumnya 50. Dalam penelitian ini jumlah sampel yang ditentukan yaitu 103 orang.

Tabel 1. Instrumen Penelitian

\begin{tabular}{l|ll|l}
\hline \multicolumn{1}{c|}{ Variabel } & \multicolumn{1}{c}{ Indikator } & \multicolumn{1}{c}{ Sumber } \\
\hline Sikap Terhadap Iklan & 1 & Informasi Yang Baik. & \\
(STI) & 2 & Informasi Yang Relevan & \\
& 3 & Informasi Terbaru & \\
& 4 & Menghibur & Ramdhani \& Abdurrahman (2021) \\
& 5 & Menyenangkan & \\
& 6 & Menarik & \\
& 7 & Dapat Diandalkan & \\
Kesadaran Merk & 8 & Dapat Dipercaya & \\
(KM) & 9 & Meyakinkan & \\
Sikap Terhadis (2017) \\
(STM) & 10 & Mengganggu & \\
& 11 & Tidak Menarik & \\
Minat & 1 & Mengingat Kembali & \\
(M) & 2 & Lebih Mengenal Iklan & \\
& 3 & Cepat Mengingat Karateristik Iklan & \\
& 1 & Mengingat Merk Tertentu & \\
& 2 & Menyukai Merk Tertentu & \\
\hline
\end{tabular}

Sumber: Kajian Literatur Diolah (2021)

Hasil

Data hasil kuesioner berupa gambaran umum responden berupa usia, pendidikan, penghasilan dan aktivitas melihat Tabel 2 yaitu sebagian besar responden berusia 18 - 25 tahun yakni sebanyak 81 orang dengan mayoritas pendidikan lulusan SMA/SMK sebanyak 59 orang. Penghasilan rata -rata terbanyak yaitu kurang dari 
dua juta rupiah. Adapun aktivitas yang dilakukan secara berturut - turut dari yang terbanyak yaitu pelajar atau mahasiswa, bekerja, wirausaha, tidak bekerja dan lainnya.

Tabel 2. Karakteristik Responden

\begin{tabular}{llrr}
\hline & Kriteria & Jumlah & $\%$ \\
\hline Usia & $18-25$ tahun & 81 & $79 \%$ \\
& $26-35$ tahun & 14 & $14 \%$ \\
& $36-45$ tahun & 6 & $6 \%$ \\
& $45-55$ tahun & 2 & $2 \%$ \\
\hline Pendidikan & SD dan SMP & 1 & $1 \%$ \\
& SMA/SMK & 59 & $57 \%$ \\
& D3 & 8 & $8 \%$ \\
& S1 & 33 & $32 \%$ \\
\hline Penghasilan & $<2$ juta & $58 \%$ & $58 \%$ \\
& 2 juta -4 juta & $18 \%$ & $18 \%$ \\
& 4.1 juta -6 juta & $12 \%$ & $12 \%$ \\
& $>6$ Juta & $7 \%$ & $7 \%$ \\
\hline Aktivitas & Bekerja & 40 & $39 \%$ \\
& Tidak Bekerja & 7 & $7 \%$ \\
& Wirausaha / Wiraswasta & 10 & $10 \%$ \\
& pelajar mahasiswa & 43 & $42 \%$ \\
& Lainnya & 3 & $3 \%$ \\
\hline
\end{tabular}

Sumber: Data Diolah (2021)

Tabel 3. Nilai Factor Loading

\begin{tabular}{ccc}
\hline Item Pernyataan & Factor Loading & Keputusan \\
\hline Sikap Terhadap Iklan (STI) & & \\
STI1 & 0.782 & Valid \\
STI2 & 0.725 & Valid \\
STI3 & 0.679 & Tidak Valid \\
STI4 & 0.725 & Valid \\
STI5 & 0.885 & Valid \\
STI6 & 0.844 & Valid \\
STI7 & 0.836 & Valid \\
STI8 & 0.856 & Valid \\
STI9 & 0.824 & Valid \\
STI10 & -0.519 & Tidak Valid \\
STI11 & -0.432 & Tidak Valid \\
Kesadaran Merk (KM) & & \\
KM1 & 0.911 & Valid \\
KM2 & 0.891 & Valid \\
KM3 & 0.832 & Valid \\
Sikap Terhadap Merk (STM) & & \\
STM1 & 0.796 & Valid \\
STM2 & 0.913 & Valid \\
STM3 & 0.911 & Valid \\
Minat (M) & & \\
M1 & 0.799 & Valid \\
M2 & 0.873 & Valid \\
M3 & 0.837 & Valid \\
M4 & 0.815 & Valid \\
M5 & 0.819 & Valid \\
\hline
\end{tabular}

Sumber: Data Diolah (2021) 
Tabel 4 Validitas Diskriminan

\begin{tabular}{lllll}
\multicolumn{1}{r}{ Konstuk } & \multicolumn{1}{r}{ STI } & \multicolumn{1}{c}{ KM } & \multicolumn{1}{c}{ STM } & M \\
\hline STI & $(0.750)$ & & & \\
KM & 0.654 & $(0.878)$ & & \\
STM & 0.361 & 0.543 & $(0.875)$ & \\
M & 0.535 & 0.479 & 0.467 & $(0.829)$ \\
\hline
\end{tabular}

Sumber: Data Diolah (2021)

Tabel 5 Average Variance Extracted

\begin{tabular}{ll} 
Konstruk & AVE \\
STI & 0.647 \\
KM & 0.771 \\
STM & 0.765 \\
M & 0.687 \\
\hline
\end{tabular}

Sumber: Data Diolah (2021)

Tabel 6 Reliabilitas

\begin{tabular}{lccc}
\multicolumn{1}{c}{ Konstruk } & Cronbach Alpha & Composite Reliability & Keterangan \\
\hline STI & 0.830 & 0.889 & Reliabel \\
KM & 0.851 & 0.910 & Reliabel \\
STM & 0.844 & 0.907 & Reliabel \\
M & 0.886 & 0.917 & Reliabel \\
\hline
\end{tabular}

Sumber: Data Diolah (2021)

Dua puluh dua item pertanyaan seperti yang tersaji pada Tabel 3 selanjutnya diuji validitasnya dengan hasil uji convergen validity menghasilkan factor loading minimal 0.7 adapun tiga inidkator yaitu STI3, STI10 dan STI11 nilainya kurang memenuhi. Berdasarkan hasil tersebut, ketiga pertanyaan dikeluarkan dari analisis. Sembilan belas pernyataan yang tersisa adalah data yang digunakan dalam analisis yang dapat mewakili ketiga variabel yang dihilangkan. Pada model ini tidak adanya permasalah validitas konvergen hal tersebut didukung pula dengan nilai Average Variance Extracted (AVE) dari masing - masing variabel yang memiliki nilai $>0,5$ yang dapat dilihat pada tabel 5. Selanjutnya yang diuji adalah permasalahan yang terkait dengan validitas diskriminan. Validitas diskriminan dapat di uji dengan melihat dari tabel cross loading seperti yang tersaji pada tabel 4. Adapun pada tabel 6 menggambarkan seluruh variabel melalui nilai cronbach alpha dan composite reliability menghasilkan nilai lebih besar dari 0.7 artinya semua variabel dapat dikatakan reliabel. Pengujian selanjutnya yaitu menguji tujuh hipotesis yang telah dikemukakan sebelumnya melalui uji model struktural. Adapun model penelitian digambarkan oleh gambar 1 sebagai berikut.

Gambar 1. Model Struktural

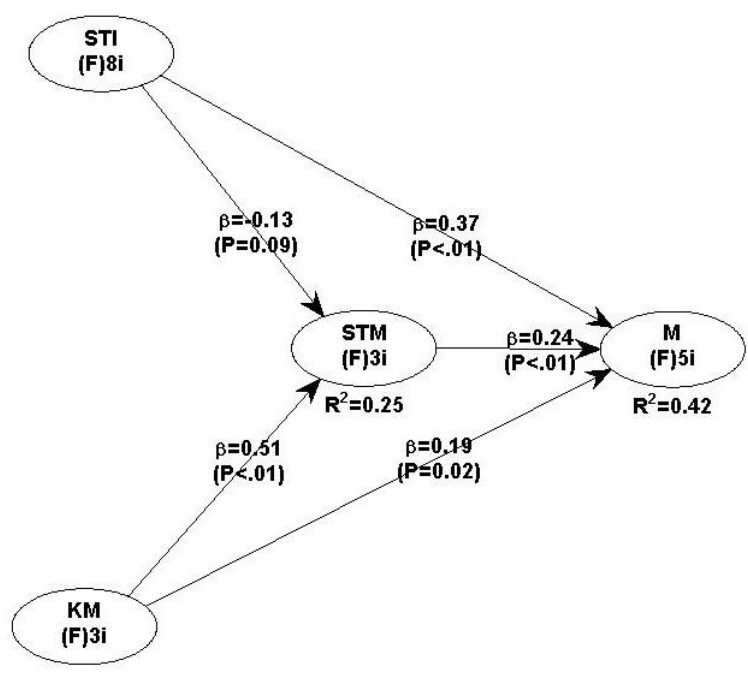

Sumber: Data Diolah (2021) 
Tabel 7 Hasil Uji Pengaruh Langsung

\begin{tabular}{|c|c|c|c|}
\hline Jalur & Koefisien & $p$-value & Effect Size \\
\hline STI $\rightarrow$ STM & -0.126 & 0.094 & 0.052 \\
\hline $\mathrm{KM} \rightarrow \mathrm{STM}$ & 0.514 & $<0.001$ & 0.300 \\
\hline $\mathrm{STM} \rightarrow \mathrm{M}$ & 0.240 & 0.005 & 0.114 \\
\hline $\mathrm{STI} \rightarrow \mathrm{M}$ & 0.366 & $<0.001$ & 0.207 \\
\hline $\mathrm{KM} \rightarrow \mathrm{M}$ & 0.187 & 0.024 & 0.099 \\
\hline \multicolumn{4}{|c|}{ Indikator goodness of fit model } \\
\hline APC & 0.286 & $p<0.001$ & \\
\hline ARS & 0.334 & $p<0.001$ & \\
\hline AVIF & 1.533 & $p<0.001$ & \\
\hline
\end{tabular}

Sumber: Data Diolah (2021)

Tabel 8 Hasil Uji Mediasi

\begin{tabular}{ccc}
\multicolumn{1}{c}{ Jalur } & Indirect effects & $p$-value Indirect effect \\
\hline $\mathrm{STI} \rightarrow \mathrm{STM} \rightarrow \mathrm{M}$ & -0.030 & 0.331 \\
$\mathrm{KM} \rightarrow$ STM $\rightarrow \mathrm{M}$ & 0.123 & 0.036 \\
\hline
\end{tabular}

Sumber: Data Diolah (2021)

Nilai Average Variance Inflation Factor (AVIF) yang disajikan melalui tabel 7 nilainya 1.533 atau kurang dari 5, menandakan bahwa model penelitian tidak mengalami multikolinieritas. Kriteria lain untuk mencapai goodness of fit model yaitu dengan melihat nilai Average Path Coefficient (APC) dan Average R-Square (ARS) pada nilai $1 \%$. Melalui nilai AVIF, APC, dan ARS tersebut dapat dikatakan bahwa model penelitian berada pada kriteria baik.

\section{Pembahasan}

\section{Pengaruh Sikap Terhadap Iklan terhadap Sikap Terhadap Merek}

Hipotesis 1 seperti yang tergambar melalui gambar 1 , tabel 7 dan tabel 8 hasilnya ditolak dengan nilai negatif $\beta=$ - 0.126; $p$-value $=0.094$. Artinya bahwa sikap terhadap iklan tidak mempengaruhi sikap terhadap merk. Hal ini bertentangan dengan penelitian yang dilakukan oleh Hakim \& Susilowati (2013) yang penelitiannya menghasilkan kesimpulan yakni sikap pada merek dipengaruhi secara postif dan signifikan oleh sikap terhadap iklan serta menurut Ramdhani \& Abdurrahman (2021) sikap terhadap iklan berpengaruh pada kesadaran merek. Hasil ini menandakan bahwa sikap konsumen terhadap iklan, baik itu informasi yang diberikan melalui iklan, cara penyampaian iklan, keyakinan terhadap iklan untuk aplikasi investasi daring dengan merek tertentu tidak mempangaruhi sikap konsumen terhadap merek aplikasi investasi daring tersebut. Pada kasus ini, sikap terhadap iklan aplikasi investasi daring tidak mempengaruhi bagaimana konsumen mengingat, menyukai dan memilih merek aplikasi investasi daring tertentu.

\section{Pengaruh Kesadaran Merek terhadap Sikap Terhadap Merek}

Hipotesis 2 pada penelitian ini diterima dengan nilai $\beta=0.514$. Hasil tersebut menunjukkan bahwa faktor kesadaran merek berpengaruh secara positif dan signifikan terhadap sikap terhadap merk. Artinya, minat menggunakan aplikasi investasi daring dapat meningkat seiring dengan meningkatnya kesadaran merek. Hasil ini semakin menguatkan pendapat Adisti (2017), Apsyari \& Raharjo (2018), Hakim \& Susilowati (2013) yang menyatakan bahwa sikap terhadap merek dipengaruhi oleh kesadaran merek. Semakin masyarakat sadar pada merek tertentu maka akan mempengaruhi sikapnya akan merek tersebut. Hasil ini menandakan bahwa semakin konsumen sadar akan merek suatu aplikasi investasi daring dengan arti bahwa konsumen ingat, mengenal dan hafal akan karakteristik suatu merek aplikasi investasi daring itu, maka hal ini berpengaruh terhadap bagaimana sikap konsumen terhadap merek aplikasi investasi daring tersebut. Semakin baik kesadaran akan mereknya maka konsumen akan semakin mengingat, menyukai dan memilih merek aplikasi investasi daring tersebut. 


\section{Pengaruh Sikap Terhadap Merek terhadap Minat Menggunakan Aplikasi Investasi Daring}

Hipotesis 3 menunjukkan hasil hipotesis diterima artinya bahwa sikap terhadap merk berpengaruh terhadap minat menggunakan aplikasi investasi daring dengan nilai diterima sebab $\beta=0.240 ; p$-Value $=0.005$. Hal ini sama - sama menghasilkan kesimpulan bahwa variabel minat menurut Rahmaniah (2019), Apsyari \& Raharjo (2018), Adisti (2017), Andrew (2014), Hakim \& Susilowati (2013), secara positif dan signifikan dipengaruhi oleh sikap terhadap merek. Serta menurut Amiludin \& Kartini (2019) bahwa sikap terhadap merek mempengaruhi konsumen untuk dapat berminat kepada produk yang dihasilkan. Hasil tersebut menandakan minat konsumen pada aplikasi investasi daring tertentu akan meningkat seiring dengan sikap terhadap merek pada aplikasi investasi daring tersebut. Artinya semakin konsumen mengingat, menyukai dan memilih merek aplikasi investasi daring tertentu maka minat konsumen akan semakin meningkat untuk tertarik, mencari info terkait produk sampai kepada konsumen berminat untuk menggunakan aplikasi investasi daring tersebut.

\section{Pengaruh Sikap Terhadap Iklan terhadap Minat Menggunakan Aplikasi Investasi Daring}

Hipotesis 4 juga diterima yaitu sikap terhadap iklan mempengaruhi minat menggunakan aplikasi investasi daring dengan nilai $\beta=0.366 ; p$-Value $=<0.001$. Penelitian mengenai sikap terhadap iklan diantaranya menurut Andrew (2014), Amalia (2018), Aziz \& Sulistiono (2020) yang menyatakan bahwa sikap mengenai iklan berpengaruh terhadap minat secara positif dan signifikan. Berdasarkan hasil tersebut, jika sikap konsumen terhadap iklan suatu aplikasi investasi daring positif, baik itu informasi yang diberikan melalui iklan, cara penyampaian iklan, keyakinan terhadap iklan maka minat untuk menggunakan produk aplikasi investasi daring tersebut sudah dipastikan meningkat.

\section{Pengaruh Kesadaran Merek terhadap Minat Menggunakan Aplikasi Investasi Daring}

Selanjutnya hipotesis 5 yaitu kesadaran merk berpengaruh positif signifikan terhadap minat menggunakan aplikasi investasi daring dengan nilai $\beta=0.184 ; p$-Value $=0.024$ artinya hipotesis diterima. Hasil ini juga menekankan hal yang sama yaitu menurut Dewi \& Jatra (2018), Nurhikmah et al. (2018), Sholihah (2018) bahwa kesadaran merek mempengaruhi minat beli. Hal ini artinya bahwa semakin konsumen mengingat dan mengenali merek serta karaktersitik merek suatu aplikasi investasi daring tertentu maka minat konsumen untuk menggunakan aplikasi investasi daring tersebut semakin tinggi.

\section{Pengaruh Tidak Langsung}

Hasil uji pengaruh tidak langsung atau mediasi dapat dilihat dari nilai $p$ - value Indiret effect. Jika nilainnya < dari $5 \%$ maka variabel tersebut dapat dikatakan memediasi variabel lain. Varibel yang mempengaruhi minat melalui mediasi variabel lain yakni berdasar hipotesis 6 dan hipotesis 7. Hipotesis 6 menggambarkan hasil yaitu sikap terhadap merek tidak memediasi sikap terhadap iklan terhadap minat menggunakan aplikasi investasi daring karena nilai $p$ - value Indiret effect $>$ dari $5 \%$ yaitu sebesar 0.331 maka hipotesis ditolak. Artinya minat konsumen dalam menggunakan aplikasi investasi daring tidak dipengaruhi oleh sikap terhadap iklan aplikasi investasi tertentu melalui sikap terhadap mereknya. Berbeda dengan penelitian yang dilakukan oleh Hakim \& Susilowati (2013) bahwa sikap terhadap iklan berpengaruh terhadap terhadap minat melalui sikap terhadap merek. Namun hipotesis 7 diterima yaitu sikap terhadap merek memediasi pengaruh kesadaran merek terhadap minat menggunakan aplikasi investasi daring dengan nilai $p$ - value Indiret effect $<$ dari $5 \%$ yaitu sebesar 0.036 . Hasil ini menandakan bahwa minat konsumen pada aplikasi investasi daring tertentu akan meningkat seiring dengan kesadaran merek pada aplikasi investasi daring tersebut melalui sikap terhadap merek suatu aplikasi investasi daring.

\section{Kesimpulan}

Kesimpulan yang dihasilkan pada penelitian ini yaitu bahwa minat menggunakan aplikasi investasi daring atau investasi berbasis aplikasi dipengaruhi secara langsung oleh variabel sikap terhadap merek, sikap terhadap iklan dan kesadaran merek. Adapun secara tidak langsung, minat menggunakan aplikasi investasi daring dipengaruhi oleh kesadaran merek melalui sikap terhadap merek.

Implikasi manajerial berdasarkan hasil penelitian khususnya bagi penyedia berbagai investasi berbasis aplikasi untuk memperhatikan beberapa hal antara lain yang berkaitan dengan sikap konsumen atau pengguna investasi berbasis aplikasi terhadap merk, yaitu mencakup bagaimana pelanggan dapat mengingat, menyukai dan memilih merek investasi berbasis aplikasi tertentu untuk dapat digunakan sebagai media investasi berbasis aplikasi. Selain itu berdasarkan hasil penelitian ini pula menyatakan bahwa sikap konsumen terhadap iklan yang ditampilkan penyedia sangat mempengaruhi minat konsumen, maka iklan yang dibuat haruslah memenuhi 
kriteria antara lain memberikan informasi yang baik, relevan, terbaru, mengghibur, menyenangkan, menarik, dapat diandalkan, dapat dipercaya dan meyakinkan. Terakhir, selain sikap konsumen terhadap merek dan iklan, kesadaran merk yang tumbuh dalam benak konsumen juga mempengaruhi minat penggunaan investasi berbasis aplikasi hal ini berdampak pula dari iklan yang disajikan. Terlepas dari ketiga hal tersebut kepercayaan yang tumbuh dari konsumen menjadi modal utama bagi konsumen untuk berminat dan merujuk memilih investasi berbasis aplikasi dengan merek tertentu.

Daftar Pustaka

Adisti, P. (2017). Pengaruh Kualitas Pesan Iklan, Kualitas Produk, Kesadaran Merek Terhadap Minat Beli Serta Citra Merek dan Sikap Terhadap Merek Sebagai Variabel Intervening. Diponegoro Journal Of Management, 6(4), 13.

Amalia, Siti N. A. (2018). Faktor-Faktor Yang Mempengaruhi Minat Individu Terhadap Financial Technology (Fintech) Syariah (Paytren) Sebagai Salah Satu Alat Transaksi Pembayaran (PendekatanTechnology acceptance model (TAM) dan Theory of Planned Behavior (TPB). Iqtishaduna Volume IX, Nomor 1, Juni 2018.

Amiludin, T., \& Kartini, D. (2019). Advertisement Attitude Dan Brand Attitude Sebagai Determinan Minat Beli (Studi Kasus pada Distro iwearzule Bandung). Skripsi UNIKOM Bandung.

Andrew, Gunawan. (2014). Aplikasi Technology Acceptance Model Pada Minat Nasabah Untuk Menggunakan Internet Banking. Jurnal Nominal / Volume III Nomor 2 / Tahun 2014

Apsyari, F. \& Raharjo D., T. (2018). Pengaruh Kesadaran Merek, Citra Merek, Loyalitas Merek terhadap Keputusan Pembelian dengan Sikap Merek Sebagai Variabel Intervening Pada Online Travel Agent Tiket.Com. Diponegoro Journal of Management Volume 7, Nomor 2, Tahun 2018

Azis, M. S. A., \& Harsono, S. (2020). Pengaruh Citra Merek, Kepercayaan Merek dan Sikap Merek terhadap Minat Menjadi Nasabah Tabungan dan Giro Bank Panin (Studi pada Bank Panin KCP Tambak Langon Surabaya). Jurnal Bisnis dan Perbankan UMSIDA, 6(2), 14.

Aziz, M. L., \& Sulistiono, S. (2020). Pengaruh Sikap Konsumen, Periklanan, dan Brand Image Terhadap Minat Beli Konsumen The Jungleland Adventure Theme Park. Jurnal IImiah Pariwisata Kesatuan, 1(1), 43-52. https://doi.org/10.37641/jipkes.v1i1.326

Cahya, A. D., \& Setyarini, E. (2020). Menguji Keputusan Berinvestasi Dari Perspektif Pembelajaran Pasar Modal, Kemajuan Teknologi, Uang Saku Mahasiswa Dan Bauran Pemasaran (Galeri Investasi Bursa Efek Indonesia Fakultas Ekonomi UST). Upajiwa Dewantara, 4(1), 13.

Darwati, A. M., \& Yulianto, E. (2019). Pengaruh Penggunaan Western Model Sebagai Brand Ambassador Terhadap Sikap Pada Iklan Serta Dampaknya Terhadap Minat Beli. Jurnal Administrasi Bisnis (JAB), 69(1), 10.

Dewi, D. A. D. P., \& Jatra, I. M. (2018). Peran Brand Awareness Dalam Memediasi Pengaruh Daya Tarik Iklan Terhadap Niat Beli. E-Jurnal Manajemen 29. https://doi.org/10.24843/EJMUNUD.2018.v7.i08.p20

Hakim, R. T., \& Susilowati, C. (2013). Pengaruh Persepsi Iklan, Kesadaran Merek, Citra Merek terhadap Sikap pada Merek dan Keputusan Pembelian (Studi pada Produk Pestisida Merek Sidamethrin 50 EC). Jurnal Aplikasi Manajemen, 11(4), 10.

Hanfan, A. (2017). Mengeksplorasi kesadaran merek terhadap minat beli ulang melalui sikap terhadap merek. Performance, 24(2), 8. https://doi.org/10.20884/1.performance. 2017.24.2.699

Heriyati, H., Pasinringi, S. A., \& Sidin, I. (2018). Brand Attitude Pasien Rawat Inap Terhadap Minat Pemanfaatan Kembali Pelayanan Di Rumah Sakit. Journal of Health, Education and Literacy, 1(1), 1-10. https://doi.org/10.31605/j-healt.v1i1.146

Kontan. (2021). Meski Ada Pandemi Jumlah Investor Pasar Modal Masih Meningkat. https://investasi.kontan.co.id/news/meski-ada-pandemi-jumlah-investor-pasar-modal-masih-meningkat. Diakses pada 01/07/2021 pukul 20.08 WIB

Manuel, H. (2019). Pengaruh Kemudahan, Keamanan, Kepercayaan Dan Kualitas Informasi Pada Aplikasi Investasi Online Terhadap Minat Investasi Saham. Jurnal IImiah Mahasiswa FEB Universitas Brawijaya, $7(2), 30$. 
Mardalena, N. T., Lubis, A. R., \& Utami, S. (2018). Pengaruh Kesadaran Merek, Kepercayaan Merek Dan Keunggulan Produk Terhadap Minat Beli Produk Luxuri Fashion Brand Dengan Gender Sebagai Moderating Pada Pemasaran Media Sosial Di Kota Banda Aceh. Jurnal Magister Manajemen Fakultas Ekonomi dan Bisnis Unsyiah, 2(1), 16.

Muslimawati, C., \& Wardani, D. K. (2017). Pengaruh Promosi Melalui Media Sosial Dan Kesadaran Merek Terhadap Minat Beli Air Minum Dalam Kemasan Dengan Merek Aqua Pada Mahasiswa Pendidikan Ekonoml FKIP UNS. Jurnal Pendidikan Bisnis dan Ekonomi UNS, Surakarta, 3(2), 19.

Nurhikmah, Romadhoni, B., \& Nurinaya. (2018). Pengaruh Brand Awareness Dan Brand Attitude Terhadap Minat Pembelian Konsumen Pada Produk Indihome Di Wilayah Telekomunikasi (Witel) Makassar. Balance: Jurnal Ekonomi, 14(2), 9.

ojk. (2021). https://reksadana.ojk.go.id/Public/TagSearchPublic.aspx?search=. Diakses pada 03/07/2021 pukul 21.45 WIB

Priyanti, Y., Susanti, F., \& Aziz, N. (2017). Minat Beli Konsumen Toko Sepatu Bata Dipasar Raya Padang Dilihat Dari Sikap Dan Iklan. Jurnal Pundi, 1(2). https://doi.org/10.31575/jp.v1i2.17

Putra, A. (2014). Pengaruh Iklan Dan Kepercayaan Merek Terhadap Minat Beli Konsumen (Studi Pada Texas Chicken Pekanbaru). JOM FISIP, 4(1), 11.

Rahmah, N. (2015). Pengaruh Kredibilitas Endorser Iklan Sensodyne Pada Sikap Konsumen (Terhadap Iklan dan Produk) dan Minat Beli Konsumen (Studi pada Mahasiswa Universitas Brawijaya Malang). Jurnal Ekonomi Bisnis, 20(1), 11.

Rahmaniah, I. (2019). Pengaruh Harga Dan Citra Merek Terhadap Minat Beli Produk Fashion Imitasi Dengan Sikap Sebagai Variabel Intervening. Skripsi Jurusan Manajemen Fakultas Ekonomi Dan Bisnis Islam Universitas Islam Negeri Alauddin Makassar.

Ramdhani, M., \& Abdurrahman, M. S. (2021). Pengaruh Sikap Terhadap Iklan Online Realme Di Youtube Dengan Kesadaran Merek Pada Masyarakat Bandung. e-Proceeding of Management, 8(2), 14.

Santoso, D. A., Erdiansyah, R., \& Pribadi, M. A. (2019). Pengaruh Brand Awareness dan Brand Image terhadap Minat Beli Produk Kecantikan Innisfree. Prologia, 2(2), 286. https://doi.org/10.24912/pr.v2i2.3589

Sholihah, Maratush. (2018). Pengaruh Brand Awareness, Norma Subyektif, Keyakinan Label Halal Terhadap Brand Attitude Untuk Meningkatkan Minat Beli Ulang Ice Cream Magnum. upajiwa dewantara, 2(2), 112124. https://doi.org/10.26460/mmud.v2i2.2021

Sholihin, M \& Ratmono, D. (2020). Analisis SEM - PLS dengan WarpPIs 7.0. CV Andi Offset : Yogyakarta. 